\title{
Induction of mixed function oxidase activity in honey bee as a bioassay for detection of environmental xenobiotics
}

\author{
N Kezić 1, D Lucić 2, D Sulimanović 3
}

\author{
1 University of Zagreb, Agricultural Faculty, Department for Aquaculture, \\ Apiculture and Special Zoology, PO Box 5196, Svetosimunska Cesta 25, 41000 Zagreb; \\ 2 Ruder Boskovic Institute, Center for Marine Research Zagreb, PO Box 1016, 41001 Zagreb; \\ 3 University of Zagreb, Veterinary Faculty, Department for Biology and Pathology of Fish and Bees, \\ Heinzelova 55, 41000 Zagreb, Republic of Croatia
}

(Received 25 April 1991; accepted 30 January 1992)

\begin{abstract}
Summary - The level of benzo-(a)-pyrene monooxidase (B(a)PMO) activity in honey bees exposed to a sugar syrup containing benzo(a)pyrene $(B(a) P)$ increased after 2 days of exposure. For different doses and at all concentrations, maximal induction (5-25-fold) was obtained on the 9th day of the experiment. At the next measurement (13th day), the B(a)P activity had decreased at all concentrations. Finally, 20 days after exposure the result was near the control values. The results showed good correlation between the dose and the activity of $\mathrm{B}(\mathrm{a}) \mathrm{PMO}$. From many drugs used for the treatment against Varroa jacobsoni, we tested the recommended and most effective drugs, Apitol and Apistan. Both drugs increased B(a)PMO activity slightly less than the lowest dose of $\mathrm{B}(a) \mathrm{P}$. The dose of $5.5 \mathrm{mg} / \mathrm{kg}$ bw (body weight of bees) B(a)P increased B(a)PMO activity by $480 \%$. The dose of Apitol recommended by the producer increased B(a)PMO activity by $300 \%$, and the recommended dose of Apistan increased the activity by $380 \%$. Mixed function oxidase (MFO) activity could also measure harmful effects of pollutants in bees as early, sublethal, objectively (ie instrumentally) measurable biochemical parameters.
\end{abstract}

Apis mellifera / mixed function oxidase / sublethal effect / acaricide / Varroa disease

\section{INTRODUCTION}

Honey bees are exposed to various harmful chemicals in the environment. As a pollinator, the honey bee is an integral part of modern agriculture. Pesticides also play an important role in the agricultural ecosystem. The contact of bees and pesticides is therefore unavoidable.
Bees can also come into the contact with harmful chemicals in the hive. Treatments against different honey bee diseases and pests, particularly Varroa mites, involve use of chemicals in the hives. In countries suffering from Varroa mites there is a considerable utilization of pesticides by beekeepers (Sulimanovic et al, 1987). 
Hazard from different chemicals are commonly expressed as acute mortality $\left(L D_{50}\right)$. It is important to be able to identify the hazards associated with honey bee exposure to sublethal pesticide doses. For sublethal effects it was suggested that worker longevity be used as a parameter (Smirle et al, 1984).

The assessment of harmful effects of pollutants requires early, sublethal, objectively (ie instrumentally) measurable biochemical parameters. Measurement of mixed function oxidases (MFO) activity could meet this demand. Aryl hydrocarbon hydroxylase $(\mathrm{AHH})$, an enzyme of the microsomal MFO group also known as benzo(a)pyrene-3-hydroxylase, may be induced by a number of exogenous air, water and food pollutants such as polycyclic aromatic hydrocarbons (PAH) and halogenated hydrocarbon herbicides and pesticides (Gelboin and Wiebel, 1971; Busbee et al, 1978; Brattsten, 1979a). The effect of $\mathrm{AHH}$ has been demonstrated in a variety of animals ranging from mammals to poikilothermic vertebrates (Batel et al, 1983; Kezic et al, 1983).

MFO is important in the detoxification of poisonous compounds and is a good indicator of general detoxification capacity (Brattsten, 1979b; Yu et al, 1984; Kezic et al, 1989). Smirle and Winston (1988) have studied the relationships between colony polysubstrate monooxidase activity and intercolony variation in susceptibility to pesticides. They have also studied the relationship between insecticide resistance, detoxifying enzyme capacity and seasonal fluctuation in these enzyme levels.

It has been established that microsomal cytochrome P-450-dependent MFO are present in bees, and like the MFO in mam. mals, are involved in the metabolism or biotransformation of xenobiotics (Payne and Penrose, 1975; Kezic et al, 1983; Smirle and Winston, 1987).

Time-dependent and dose-dependent increase in activity of the detoxifying enzymes after contact with common inducer benzo (a)pyrene $(\mathrm{B}(\mathrm{a}) \mathrm{P})$ was analyzed. The possibility of inducing MFO by feeding bees with honey from a polluted area (Zagreb; town center) and with honey from a less polluted area (Glina; village area) was tested). Induction of MFO activity was measured in the bees exposed to common drugs used for treatment against Varroa disease.

\section{MATERIAL AND METHODS}

\section{Chemicals}

$\mathrm{B}(\mathrm{a}) \mathrm{P}$ and 7,8-benzoflavone (BF) were obtained from Roth (Karlsruhe, Germany); NADPH and chemicals used in the benzo(a)pyrene monooxidase (B(a)PMO) activity determination were from Sigma (Heidelberg, Germany) and fluorescent grade hexane was from Merck (Darmstadt, Germany). Benzo(a)pyrene hydroxide ( $\mathrm{B}(a) \mathrm{POH})$ was generously donated by $\mathrm{H}$ Gelbouin $(\mathrm{NIH}$, Bethesda, USA). All the other chemicals used were of analytical grade.

\section{Bees}

Frames of sealed brood were removed from the colony and workers were allowed to emerge overnight in a laboratory incubator $\left(34^{\circ} \mathrm{C}\right)$. Next day emerged workers were divided into 4 cages and placed in a laboratory incubator. Cages were patterned after those described by Kulincevic and Rothenbuhler (1973). Honey bees were fed in cages overnight with sugar syrup ( $w / w$ ratio $1: 1$ ), and sugar syrup with addition of $\mathrm{B}(\mathrm{a}) \mathrm{P}(5.5,16.5$ and $50 \mathrm{mg} / \mathrm{kg}$ body weight). The next days bees in all cages were fed with sugar syrup. Bees were killed 2, 9, 13 and 20 days after commencement of feeding. 
Worker bees from equal strength bee colonies from Langstroth beehives and treated with standard doses of Apitol and Apistan and untreated workers were examined after 9 days.

Honey collected from 20 beehives placed throughout the year in the center of town (Zagreb, Republic of Croatia) surrounded by heavy traffic was used for bee feeding in cages. The induction of $\mathrm{B}(\mathrm{a}) \mathrm{PMO}$ was correlated with the $\mathrm{B}$ (a)PMO activity of the honey collected from 20 beehives in a village surrounded by meadows and woods (Glina, Republic of Croatia).

\section{Preparation of subcellular fraction}

Postmitochondrial fractions (PMF) were prepared by homogenization of pooled bees (10 specimens), in 5 vol of $50 \mathrm{mM}$ Tris- $\mathrm{KCl}$ buffer, $\mathrm{pH} 7.6$ $(0.05 \mathrm{M}$ Tris, 0.25 sucrose in $1 \% \mathrm{KCl})$ using all glass Potter-Elvehjem and Polytron (Kinematica, Switzerland) homogenizers. The homogenate was centrifuged at $+4{ }^{\circ} \mathrm{C}$ for $10 \mathrm{~min}$ at $9000 \mathrm{~g}$ and the supernatant was used as postmitochondrial fraction (enzyme source for B(a)PMO).

\section{Measurement of B(a)PMO activity}

The activity of $\mathrm{B}(\mathrm{a}) \mathrm{MPO}$ was determined by using the method of Nebert and Gelboin (1968) with modifications by Payne and Penrose (1975). Activity was expressed as pmol of $B(a)$ $\mathrm{POH}$ per $\mathrm{mg}$ of protein per min. BF was added in parallel runs to the incubation medium to a final concentration of $5 \cdot 10^{-5} \mathrm{~mol} / \mathrm{l}$. Protein content was determined according to the method of Lowry et al (1951).

Analysis of variance techniques followed by a $t$-test were used to compare differences in the results of the $\mathrm{B}(\mathrm{a}) \mathrm{PMO}$ induction in bees after feeding with honey from a polluted area (town center) and from a less polluted area (villages), and the activity of B(a)PMO in honey bees exposed to common drugs used for treatment against Varroa disease. The correlations between time-dependent and dose-dependent activity of $\mathrm{B}(\mathrm{a}) \mathrm{PMO}$ in honey bees induced by $\mathrm{B}(a) \mathrm{P}$ were investigated. The statistical significance level used throughout these procedures was $P<0.05$ (Baric, 1965).

\section{RESULTS AND DISCUSSION}

The level of B(a)PMO activity in honey bees exposed to a sugar syrup with addition of $B(a) P$ increased after 2 days of exposure, compared to a control level (sugar syrup only). For different doses and the levels of induction tested in all concentrations, the maximal induction (5-25-fold) was obtained on the 9th day of the experiment (table I).

At the next measurement (13th day) the $\mathrm{B}(\mathrm{a}) \mathrm{P}$ activity was lower in all the concentrations and finally 20 days after exposure the activity was near control values. The results showed good correlation (2nd day, $r=$ 0.8193 ; 9 th day, $r=0.8544 ; 13$ th day, $r=$ 0.9611 ; 20 th day, $r=0.9057$ ) between the dose and the activity of $\mathrm{B}(\mathrm{a}) \mathrm{PMO}$. The activity of $\mathrm{B}(\mathrm{a}) \mathrm{PMO}$ in the control group (sugar syrup only) was within the range of the basal activity up to 20 days after exposure.

BF is commonly known as an inhibitor of MFO activity (Malavelle and Bartsch, 1984). In our experiments BF exhibited an inhibition range between $15 \%$ at the lowest concentration and $57 \%$ at the highest concentration (table II). In the control group in-

Table I. The time-dependant and dosedependent activity of $\mathrm{B}(\mathrm{a}) \mathrm{PMO}$ in Apis mellife$\mathrm{ra} L$ induced by $B(a) P \mathrm{mg} / \mathrm{kg}$ body weight in sugar syrup.

\begin{tabular}{lrrrr}
$\begin{array}{l}B(\mathrm{a}) P \\
(\mathrm{mg} / \mathrm{kg} \text { bw) }\end{array}$ & 2 & \multicolumn{4}{c}{ Activity (days) * } \\
& & 9 & 13 & 20 \\
\hline & & & & \\
\hline & 1.54 & 1.85 & 1.95 & 1.99 \\
5.50 & 6.76 & 10.25 & 5.99 & 3.74 \\
16.50 & 19.28 & 45.70 & 9.25 & 7.03 \\
50.00 & 20.50 & 52.50 & 15.02 & 8.75 \\
\hline
\end{tabular}

* Activity expressed as pmol of $\mathrm{B}(\mathrm{a}) \mathrm{POH} / \mathrm{mg}$ protein/ min. 
Table II. The influence of BF on B(a)PMO activity in bees exposed to different doses of $\mathrm{B}(a) \mathrm{P} 20$ days after exposure.

\begin{tabular}{cccc}
\hline $\begin{array}{c}B(\mathrm{a}) P \\
(\mathrm{mg} / \mathrm{kg} \text { bw })\end{array}$ & $\begin{array}{c}B(\mathrm{a}) P M O \\
\text { activity* }\end{array}$ & $\begin{array}{c}\text { B(a)PMO activity } \\
\text { with addition of } B F\end{array}$ & $\begin{array}{c}\text { Inhibition } \\
(\%)\end{array}$ \\
\hline 5.5 & $3.74 \pm 0.76$ & $3.18 \pm 0.10$ & 14.97 \\
16.5 & $7.03 \pm 0.37$ & $3.75 \pm 0.36$ & 46.65 \\
50 & $8.75 \pm 0.35$ & $3.74 \pm 0.15$ & 57.26 \\
Control & $1.83 \pm 0.18$ & $1.91 \pm 0.88$ & $(+4.37)$ \\
\hline
\end{tabular}

* Activity expressed as pmol of $\mathrm{B}(\mathrm{a}) \mathrm{POH} / \mathrm{mg}$ protein/min.

ibition was not present, the slight increase in activity constituting evidence of absence of induction. Dose- and time-dependent increase in $\mathrm{B}(\mathrm{a}) \mathrm{PMO}$ activity with $\mathrm{B}(\mathrm{a}) \mathrm{P}$ demonstrates the potential range of the sensitivity of this method.

Of the many drugs which are in use for the treatment against Varroa jacobsoni, the recommended and most effective drugs Apitol and Apistan were tested (Čerimagic et al, 1990). As a positive control 2 doses $(5.5$ and $50 \mathrm{mg} / \mathrm{kg} \mathrm{bw})$ of the common inducer $\mathrm{B}(\mathrm{a}) \mathrm{P}$ were correlated. The group of bees fed with sugar syrup only was used as a negative control. Both drugs increased $\mathrm{B}(\mathrm{a}) \mathrm{PMO}$ activity to a slightly lesser degree than the lowest dose of $B(a) P$. The dose of $5.5 \mathrm{mg} / \mathrm{kg}$ bw (body weight) $\mathrm{B}(\mathrm{a}) \mathrm{P}$ increased $\mathrm{B}(\mathrm{a}) \mathrm{PMO}$ activity by $480 \%$. The dose of Apitol recommended by the producer increased B(a)PMO activity by $300 \%$, and Apistan increased the activity by $380 \%$ (table III).

The results presented in table IV demonstrate the slight increase $(P<0.05)$ in $\mathrm{B}(\mathrm{a}) \mathrm{PMO}$ activity on the sugar syrup scale from the less polluted area (village area) and the polluted area (town).

Xenobiotics are mostly lipophilic and we did not expect them to exert a high influ-
Table III. The activity of B(a)PMO in Apis mellifera $\mathrm{L}$ exposed to common drugs used for the treatment against Varroa disease.

Treatment

$B(a) P M O$ activity *

Apitol

$8.08 \pm 0.41$

Apistan

$9.46 \pm 0.95$

Controls: control bees

$5.5 \mathrm{mg} \mathrm{B}(\mathrm{a}) \mathrm{P} / \mathrm{kg}(\mathrm{bw})$

$1.98 \pm 0.43$

$50.00 \mathrm{mg} \mathrm{B}(\mathrm{a}) \mathrm{P} / \mathrm{kg}(\mathrm{bw})$

$11.48 \pm 1.24$

$52.81 \pm 0.43$

* Activity expressed as pmol of $\mathrm{B}(\mathrm{a}) \mathrm{POH} / \mathrm{mg}$ protein/ $\min$.

ence on B(a)PMO activity. Incubatoremerged bees were used and, as Smirle and Winston (1987) noted, in such bees the background activity is lower.

MFO activity is the reaction on contact with xenobiotics and is correlated to dose (fig 1). These results are in good correlation with the increase found for foragers, as described by Smirle and Winston (1987). When the bees were in contact with xenobiotics, MFO activity was induced, which after reaching its maximum slowly decreased over a period of days. 
Table IV. B(a)PMO induction in experimental bee after feeding with honey from a polluted area (town center) and a less polluted area (villages).

Location $\quad$ B(a)PMO activity *

$\begin{array}{lr}\text { Town center } & 1.24 \pm 0.20 \\ \text { Village } & 1.06 \pm 0.05 \\ & \\ \text { Controls: sugar syrup } & 0.95 \pm 0.05 \\ 5 \mathrm{mg} \mathrm{B}(\text { a) } \mathrm{P} / \mathrm{kg} \text { bee } & 10.01 \pm 1.70\end{array}$

* Activity expressed as pmol of $\mathrm{B}(\mathrm{a}) \mathrm{POH} / \mathrm{mg}$ protein/ $\min$.

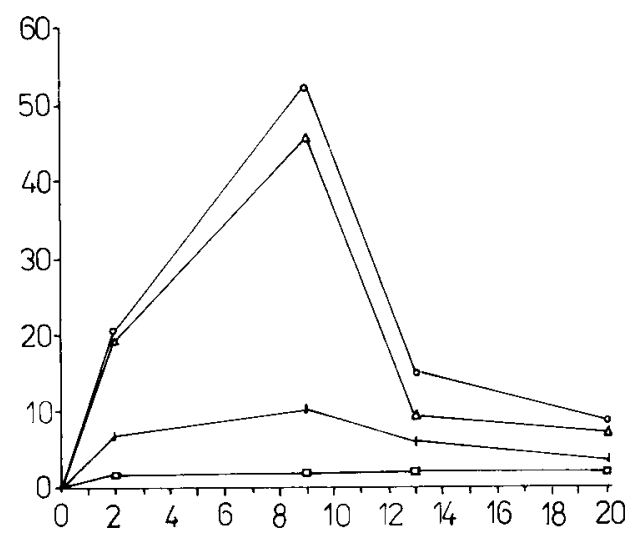

Fig 1. Dose- and time-dependent B(a)PMO activity in the honey bee.

A significant increase $(P<0.05)$ in $\mathrm{B}$ (a)PMO activity caused by exposure of honey bee colonies to new generations of drugs for the treatments of Varroa disease suggests that, although the treatment did not cause visible damage to the bee colonies, negative biological effects could be expected.
Résumé. - Induction de l'activité mono-oxygénase chez l'abeille comme test biologique pour détecter les substances toxiques de l'environnement. Le niveau d'activité de la B(a)PMO (= benzo(a)pyrène monooxygénase, enzyme qui se forme dans le corps des insectes sous l'action de substances toxiques) chez des abeilles (Apis mellifera L) mises en contact avec un sirop de sucre additionné de $\mathrm{B}(\mathrm{a}) \mathrm{P}$ est déjà plus élevé au bout de $2 \mathrm{j}$ que celui du groupe témoin (nourri uniquement au sirop de sucre). En testant les différentes doses et les niveaux d'activité, on s'aperçoit qu'il y a un maximum de déclenchement (5-25 fois) le $9^{e} \mathrm{j}$. À la mesure suivante $\left(13^{e} \mathrm{j}\right)$, l'activité de la $B(a) P$ est moindre à toutes les concentrations et finalement, le $20^{\mathrm{e}} \mathrm{j}$, elle est pratiquement revenue aux valeurs témoins. Les résultats (tableau 1) montrent une bonne corrélation entre la dose et l'activité de la B(a)PMO. Dans le groupe témoin celle-ci s'est maintenue au niveau de l'activité basale depuis le début jusqu'au $20^{\ominus} \mathrm{j}$.

Parmi les nombreux produits de traitement contre Varroa jacobsoni, nous avons testé l'Apitol et l'Apistan, produits recommandés particulièrement efficaces (Čerimagic et al, 1990). Comme témoin positif, nous avons utilisé le déclencheur classique $\mathrm{B}(\mathrm{a}) \mathrm{P}$ à 2 doses $(5,5$ et $50 \mathrm{mg} / \mathrm{kg} \mathrm{b} / \mathrm{w})$. Comme témoin négatif, nous avons pris un groupe d'abeilles nourries uniquement avec un sirop de sucre. Les 2 acaricides ont élevé l'activité de la $\mathrm{B}(\mathrm{a}) \mathrm{PMO}$ un peu moins que la plus faible dose de $B(a) P$. Une dose de $5,5 \mathrm{mg} / \mathrm{kg} \mathrm{b} / \mathrm{w}$ de $\mathrm{B}(\mathrm{a}) \mathrm{P}$ a augmenté l'activité de $480 \%$; l'Apitol, à la dose recommandée par le fabricant, a augmenté l'activité de $300 \%$ et l'Apistan de $380 \%$ (tableau III). L'augmentation significative de l'activité de la B(a)PMO due au contact des colonies d'abeilles avec une nouvelle génération de produits contre la varroatose montre que l'on peut s'attendre 
à des effets négatifs, même si le traitement ne cause pas aux colonies de dégâts visibles.

\section{Apis mellifera / monooxygénase / effet sublétal / acaricide / varroatose}

Zusammenfassung. - Auslösung der Aktivität der Mischfunktions/Oxydase bei Honigbienen als Biotest für die Entdeckung von Umweltschadstoffen. Die Höhe der Aktivität von B(a)PMO (Benzo(a) Pyren-Mono-Oxidase, ein Enzym, das im Insektenkörper unter der Einwirkung von Schadstoffen entsteht) in Honigbienen, die mit $\mathrm{B}(\mathrm{a}) \mathrm{P}$ in einer Zuckerlösung in Berührung gekommen waren, stieg im Vergleich zu einer Kontrollgruppe (gefüttert mit Zuckerlösung allein) schon zwei Tage nach der Einwirkung an. Bei der Prüfung verschiedener Dosierungen und Prüfung der Aktivitätshöhe bei allen Konzentrationen, zeigte sich ein Maximum der Induktion (5-25-fach) am Tag 9 des Experiments. Bei der nächsten Messung (am Tag 13) war die B(a)P-Aktivität für alle Konzentrationen wieder gesunken und schließlich, am Tag 20, beinahe auf die Höhe der Kontrollwerte zurückgekehrt. Die Ergebnisse (Tabelle I) zeigen eine gute Korrelation zwischen Dosis und B(a)PMOAktivität. Die Aktivität des B(a)PMO der Kontrollgruppe (Zuckerwasser allein) hielt sich bis zum Tag 20 im Rahmen der Anfangsaktivität.

Von den vielen Mitteln, die zur Behandlung von Varroa jacobsoni benutzt werden, prüften wir die besonders empfohlenen und wirksamen Mittel Apitol und Apistan (Cerimagic et al, 1990). Als positive Kontrolle benutzten wir den üblichen Auslöser $B(a) P$ in zwei Dosen $(5,5$ und $50 \mathrm{mg} / \mathrm{kg}$ b/w). Als negative Kontrolle nahmen wir eine Gruppe von Bienen, die nur mit Zuckerwasser gefüttert wurde. Beide Mittel erhöhen die Aktivität von $\mathrm{B}(\mathrm{a}) \mathrm{PMO}$ nur geringfügig weniger als die niedrigere Dosis von $\mathrm{B}(\mathrm{a}) \mathrm{P}$. Eine Dosis von $5,5 \mathrm{mg} / \mathrm{kg} \mathrm{b} / \mathrm{w}$ B(a)P erhöht die Aktivität um $480 \%$, Apitol in Dosen wie vom Erzeuger empfohlen hingegen steigert die Aktivität um $300 \%$ und Apistan um 380\% (tabelle III).

Die signifikante Erhöhung der B(a)PMOAktivität verursacht durch den Kontakt von Bienenvölkern mit einer neuen Generation von Mitteln gegen die Varroatose zeigt, daß trotz Ausbleibens sichtbarer Schäden an den Bienenvölkern durch die Behandlung, negative biologische Auswirkungen zu erwarten sind.

\section{Apis mellifera / Mischfunktions- Oxydase / subletale Wirkung / Akarizide / Varroatose}

\section{REFERENCES}

Baric S (1965) Statisticke metode prijenjene u stocarstvu. Agron glasnik 11-12, 5-124

Batel R, Bihari N, Kurelec B, Muller WEG, Zahn RK (1983) Presence of mixed function oxygenases in some marine invertebrates. Thalassia Jugosl 19, 23-29

Brattsten LB (1979a) Biochemical defence mechanisms in herbivores against plant allelochemicals. In: Herbivores: Their Interactions With Secondary Plant Metabolites (Rosental GA, Janzen DH, eds) Academic Press, New York, 199-270

Brattsten LB (1979b) Ecological significance of mixed-function oxidations. Drug Metabolism Rev 10, 35-57

Busbee DL, Guyden J, Kingston T, Rose FL, Cantrell ET (1978) Metabolism of benzo (a)pyrene in animals with high aryl hydrocarbon hydroxylase levels and high rates of spontaneous cancer. Cancer Lett 4, 61-68

Cerimagić H, Rihar J, Sulimanović D (1990) Bolesti, Stetocine i Trovanja Pcela. NIP Zadrugar, Sarajevo, 5-185

Gelboin HV, Wiebel FJ (1971) Studies on the mechanism of aryl hydrocarbon hydroxylase 
induction and its role in cytotoxicity and tumorigenicity. Ann NY Acad Sci 179, 529537

Kezic N, Britvic S, Protic M, Simmons JE, Rijavec M, Zahn RK, Kurelec B (1983) Activity of benzo(a)pyrene monooxygenase in fish from Sava river: correlation with pollution. Sci Total Environ 27, 59-69

Kezic N, Sulimanovic D, Lucić D (1989) Induction of monooxygenase activity in honey bees as a bioassay for detection of environmental xenobiotics in honey. 32nd int Congr Apiculture, Rio de Janeiro. Editions Apimondia, Bucharest, 326

Kulincevic J, Rothenbuhler WC (1973) Laborato$\mathrm{ry}$ and field measurements of hoarding behavior in the honey bee, Apis mellifera. J Apic Res 12, 179-182

Lowry OH, Rosebrough NJ, Farr AL, Randall RJ (1951) Protein measurement with the Folin phenol reagent. J Biol Chem 193, 265-275

Malavalle C, Bartsch H (1984) Metabolic activation systems in short-term in vitro tests. In: Handbood of Mutagenicity Test Procedures (Kilbey BJ, Legator M, Nichols W, Ramel C, eds) Elsevier, Amsterdam, 615-641

Nebert DW, Gelboin HV (1968) Substrate inducible microsomal aryl hydroxylase in mammali- an cell culture. I. Assay and properties of induced enzyme. J Biol Chem 243, 62426249

Payne JF, Penrose WR (1975) Induction of aryl hydrocarbon benzo(a)pyrene hydroxylase in fish by petroleum. Bull Environ Contam Toxicol 14, 112-116

Smirle MJ, WInston ML (1987) Intercolony variation in pesticide detoxification by the honey bee (Hymenoptera: Apidae). J Econ Entomol $80,5-8$

Smirle MJ, WInston ML (1988) Detoxifying enzyme activity in worker honey bees: an adaptation for foraging in contaminated ecosystems. Can J Zool 66, 1938-1942

Smirle MJ, Winston ML, Wodward KL (1984) Development of sensitive bioassay for evaluating pesticide effects on the honey bee $(\mathrm{Hy}$ menoptera; Apidae). J Econ Entomol 77, 6367

Sulimanovic D, Kezic N, Krpan Ž (1987) Sideeffects of Varroa disease. 31st Int Congr Apiculture, Warsaw. Editions Apimondia, Bucharest, 256-257

Yu SJ, Robinson FA, Nation JL (1984) Detoxication capacity in the honey bee, Apis mellifera L. Pestic Biochem Physiol 22, 360-368 